УДК 141.201

DOI: 10.18101/1994-0866-2020-2-3-8

\title{
К ВОПРОСУ О ВОЗНИКНОВЕНИИ СИСТЕМНЫХ ПРЕДСТАВЛЕНИЙ
}

\author{
(C) Багаева Ксения Анатольевна \\ кандидат философских наук, доцент, \\ Бурятский государственный университет имени Доржи Банзарова \\ Россия, 670000, г. Улан-Удэ, ул. Смолина, 24а \\ E-mail: ksyusha.81@mail.ru

\section{(C) Жапова Наталья Амогалановна} \\ кандидат философских наук, старший преподаватель \\ Бурятский государственный университет имени Доржи Банзарова \\ Россия, 670000, г. Улан-Удэ, ул. Смолина, 24а \\ E-mail: tumann4@rambler.ru
}

\begin{abstract}
Настоящая статья посвящена изучению вопроса о формировании системных представлений в истории философской мысли. Авторы отмечают, что системные представления существовали еще в древности начиная с мифологического периода. Определяется круг основных категорий, через которые философы античности, средневековья, Нового времени, а также немецкой классической философии пытались определить системность. Указано, что системные представления - это результат развития философской мысли и достижений науки. Авторы выделяют три этапа в становлении и развитии системных представлений, указывая, что именно они стали определяющими для дальнейшего развития этих взглядов. Сделан закономерный вывод о том, что в настоящее время системный подход - это общепризнанная методология для многих научных исследований, охватывающих почти все отрасли современного знания.
\end{abstract}

Ключевые слова: система; системность; целое; часть; взаимодействие; философия; категория.

\section{Для цитирования}

Багаева K. А., Жапова Н. А. К вопросу о возникновении системных представлений // Вестник Бурятского государственного университета. Философия. 2020. Вып. 2.

C.3-8.

Достижения современной науки уверенно доказывают, что окружающий мир является совокупностью взаимосвязанных и взаимодействующих объектов. Мир вокруг человека - это система, которая, в свою очередь, состоит из систем разного вида. Такое понимание мира как упорядоченной, организованной совокупности элементов можно проследить в процессе развития как науки, так и философии. Поэтому необходимо выяснить основные аспекты концептуализации понятия системных представлений в философии.

Отметим, что сегодня издано большое количество работ, посвященных системе, ее сущности, авторами которых являются как российские, так и зарубежные ученые. Общее системное представление о мире закладывалось в работах А. А. Богданова [1], Л. Берталанфи [2], Н. Винера [3], Г. Хакена [4], В. Н. Садов- 
ского [5]. Социально-философский взгляд на систему сформирован в исследованиях В. Г. Бранского [6], В. С. Степина [7] и других. Однако комплексного взгляда на развитие системных представлений в истории социальной философии не выявлено. Поэтому в данной статье предпринята попытка анализа становления системных представлений начиная с античности, заканчивая современными взглядами.

Формирование системных представлений включено в процесс развития философии и науки в целом. Отметим самые важные моменты в становлении системности в философии, которые необходимы для динамики понимания системы, логично развиваясь от первых смутных представлений до окончательно оформленных в трудах современных исследователей.

Системность складывалась наряду с развитием человеческой практики познания мира как способ мышления. По существу, уже мифологическое мировоззрение обладает целостным взглядом на мир. Даже тогда человек начинает формировать связи между происходящими процессами в природе, хотя и относит их к сверхъестественным. Усложнение взгляда происходит в следующий период, который традиционно связан с возникновением философского мировоззрения.

Еще в античности существовало понимание мира как системного и взаимосвязанного. По существу, у Аристотеля находим первое представление о системе, давая определение целого, которое состоит из частей или элементов. Философ утверждает, что разные по своей сущности объекты могут взаимодействовать друг с другом и соединяться в единое целое. Кроме того, у древнегреческого философа формулируется важная мысль о видах систем, что существуют системы, в которых целостность преобладает над элементами. Также есть системы, в которых элементы доминируют над целостностью [8]. Именно категория «целое» становится выражением взаимосвязанных множеств элементов. Вот как древнегреческий философ пишет в «Метафизике»: «Целым называется то, у чего не отсутствует ни одна из тех частей, состоя из которых, оно именуется целым от природы, а также то, что так объемлет объемлемые им вещи, что последние образуют нечто одно, а это бывает двояко: или так, что каждая из этих вещей есть одно, или так, что из всех них образуется одно. А именно: [а] общее и тем самым то, что вообще сказывается как нечто целое, есть общее в том смысле, что оно объемлет многие вещи, поскольку оно сказывается о каждой из них, причем каждая из них в отдельности есть одно...» ${ }^{1}$. Таким образом, у Аристотеля выработано понимание системы как состоящей из качественно взаимосвязанных элементов. Во многом благодаря Стагириту и его философской системе древнегреческая философия дала систематизированное математическое знание. Так, учение Евклида, отраженное им в «Началах», было одной из первых стройных систем математики.

Средневековая философия в своих попытках систематизировать христианскую философию также разрабатывала понятие системности, гносеологически рассматривая тему целостности мира. Так, примером системности может служить философия Фомы Аквинского, который с точки зрения теологии во многом интерпретировал взгляды Аристотеля. Аквинат, представляя философию и теологию единым целым, пишет, что они как единое целое не различимы, поскольку имеют

${ }^{1}$ URL: https://ru.wikisource.org/wiki/ (дата обращения: 20.03.2020). 
предметом Бога и созданный им цельный мир. Поэтому Аквинский делает главным принцип гармонии веры и разума, возводит в центр иерархический мир и Бога как начало всего мироздания.

В эпоху Возрождения идея целостного восприятия мира человеком становится определяющей. Целостность природы у философов того времени становится главным принципом. Системные воззрения находим у Николая Коперника, Джордано Бруно, Галилео Галилея, Иоганна Кеплера.

Николай Коперник создал гелиоцентрическую систему мира, которую высказал в работе «Об обращении небесных сфер». Работа сыграла важную роль не только в развитии науки, но и в пересмотре представлений о системе мира. Дело в том, что гелиоцентрическая система Коперника порывала с идеями Птолемеевской астрономии и теологическим объяснением мира, она внесла идею того, что Земля - не центр, а образует системное единство, единую Вселенную с другими планетами. Такие идеи были поддержаны Джордано Бруно, который высказывает мысль о единстве мира и бесконечности природы, подтверждая словами: «Итак, Вселенная едина, бесконечна, неподвижна. Едина, говорю я, абсолютная возможность, едина действительность, едина форма или душа, едина материя или тело, едина вещь, едино сущее, едино величайшее и наилучшее... Она не рождается, ибо нет другого бытия, которого она могла бы желать и ожидать, так как она обладает всем бытием. Она не уничтожается, ибо нет другой вещи, в которую бы она могла превратиться, так как она является всякой вещью. Она не может уменьшиться или увеличиться, так как она бесконечна... Она не материя, ибо не имеет фигуры и не может ее иметь, она бесконечна и беспредельна. Она не форма, ибо не формирует и не образует другого ввиду того, что она есть все, есть величайшее, есть единое, есть вселенная» [9].

Особая роль принадлежит мало упоминаемому философу того времени Бернардино Телезио, в творчестве которого намечается важная мысль о материальном единстве мира, именно он говорит о принципе самодвижения, который воплощается в мертвой пассивной материи.

Таким образом, философы эпохи Возрождения радикально пересмотрели взгляд на бытие как систему мира. Причем эта система понималась ими как автономная и независимая по отношению к человеку, обладающая особым типом организации, своими законами и структурой. В этом аспекте кажется верным мнение В. Н. Спицнаделя, который пишет, что «наука эпохи Возрождения выработала определенную концептуальную систему. Ее важнейшие категории - вещь и свойства, целое и часть, субстанция и атрибуты. Вещь трактовалась как сумма отдельных свойств. ...Познавательная процедура сводится к поиску сходства и различия в предметах. В связи с этим весьма специфично трактуется категория «отношение», которая выражает, прежде всего, субординацию главных и второстепенных свойств, динамическое воздействие некоего предмета на другой, первый из которых является причиной, а второй - следствием. ...Важнейшая особенность представлений о системности предмета познания, характерная для науки эпохи Возрождения, состоит в выдвижении на первый план каузального, а не телеологического способа объяснения...» [10]. Однако, с другой стороны, отметим, что в этот 
К. А. Багаева, Н. А. Жапова. К вопросу о возникновении системных представлений

период наука и философия находились только в самом начале формирования системности, поэтому отметим, что это время усиления системных тенденций в философии.

XVII век - время перемен, произошедших как в науке, так и философии. Философами того периода Б. Бэконом, Р. Декартом, Б. Спинозой, Лейбницем закладываются новые основания для науки. Так, Г. В. Лейбниц попытался создать учение, которое бы объяснило все существующее многообразие мира на основе одной субстанциональной основы. Лейбниц разрабатывает учение о монадах — простых и неделимых субстанциях, лежащих в основе мире, что очень созвучно с системным взглядом, утверждающим множественность мира, не сводимого к какой-либо одной схеме. Монады выступают у него элементами целостного мира, частями Вселенной. Субстанции - это активное, деятельное начало, существует их иерархия. Так, Г. Лейбниц пишет: «Я называю миром все следствия и всю совокупность существования вещей, чтобы уже нельзя было утверждать, будто могут существовать еще многие миры в разные времена и в разных местах. Потому что все их в совокупности следует считать за один мир, или, если угодно, за один универсум» [11].

Позднее понимание системы было развито французскими материалистами, они рассматривали природу в качестве механизма, в котором взаимодействуют неделимые элементы, которые не оказывали принципиального влияния на систему. Поэтому здесь описываемые объекты не обладали системными свойствами. Несмотря на то, что древние греки высказывали идеи о системности и создали условия для формирования философской категории «система, также и в последующих исследованиях определяли природу, знание как систему, все-таки системный подход как особая методология начинает формироваться гораздо позже.

Наиболее четко системность выразили представители немецкой классической философии. И. Кант понимал систему как единство разных типов знания, объединенных общей целью [12, с. 164]. Как верно отмечает Д. Ш. Цырендоржиева, «в этом определении Канта отражены не только такие особенности системы, как порядок, взаимообусловенность, но и отражено противоречие, а следовательно, движение, развитие» [13, с. 29]. Таким образом, Кант, стремясь создать целостное мышление, объединяет противоположности, такие как единство и множество, форма и содержание, необходимость и случайность. Поэтому Кант поясняет, что «под системой я разумею единство многообразных знаний, объединенных одной идеей» [12, с. 680]. Системность в виде структурности необходима везде, само философское знание - это система, состоящая, в свою очередь, из подсистем, элементов, система усложняется, поэтому и возможен прогресс науки.

Далее система начинает рассматриваться с точки зрения диалектики. Так, Г. Гегель заостряет внимание на принципе иерархичности, который усматривается им в соотношении целого и части. Совокупность элементов определяет существование системы, которая, в свою очередь, обусловливает существование связанных и взаимодействующих между собой элементов. Абсолютная идея - это целостность, поэтому вся система - это порождение абсолютной идеи. Закономерен вывод, что системность становится всеобщим принципом природы, человека, общества. Гегель утверждает системность мира, представляя его как систему ступеней развертывания Абсолютной идеи. Классифицируя системы, Гегель находит в них такой общий принцип, как соотношение «целого» и «части». «Целое есть самостоятельное, части суть лишь моменты», пишет философ, утверждая приоритетность 
целого над частью. Также Гегель дополняет, что «идея как конкретная в себе и развивающаяся есть, таким образом, органическая система, целостность, содержащая в себе множество ступеней и моментов» [14, с. 32]. Итак, у немецкого философа находим очень важную мысль о том, что мир - это изменение, саморазвитие идеальной системы.

Уже во второй половине XIX в. философы К. Маркс, Ф. Энгельс убедительно дают системные характеристики объектов. Исследуя общество, ученые делают вывод о его системности и структурности. К данному аспекту следует обратиться в рамках исследования общества как системы. Отметим, что К. Маркс определил ряд законов развития и деятельность общества, его элементов. А Ф. Энгельс перенес эти принципы на все, что окружает человека. Философы системность направляют на изучение общества. Они рассматривают общество как целостность на определенном этапе исторического развития, называя его общественно-экономической формацией. Именно общественно-экономическая формация, по мнению К. Маркса, - это сложная система, которая состоит из взаимосвязанных элементов. Такое общество представляет собой сложную, упорядоченную, организованную систему. Главным упорядочивающим элементом, по мнению К. Маркса и Ф. Энгельса, становится трудовая деятельность, а также возникающие на ее основе экономические отношения.

Таковы определяющие моменты в линии динамики понимания системности в истории философской мысли. Все это дает возможность предположить, что еще с античности существовали системные представления, а системность как методологическое направление сформировалась в XX в.

Таким образом, в XX в. системность становится одним из главных подходов к изучению мира. Обращаясь к указанным этапам развития системных воззрений, нужно отметить А. А. Богданова, которого по праву можно назвать основателем общей теории систем. В своих исследованиях ученый выдвинул важную идею об однородности структур любой сложности, что независимо от своей сущности структуры могут быть сравнимы на основании общей функциональности [1, с. 290].

Итак, формирование системных представлений происходило в несколько этапов. Выделим четыре этапа, первый из которых начался еще в глубокой древности и продолжался до начала XX в. Этот период отличается тем, что системность проявляется в практической деятельности людей, а потом определяется как способ мышления и особый взгляд на окружающий мир. Именно тогда создаются специальные понятия, характеризующие системность. Этому во многом способствовали открытия в науке.

Следующий этап начинается с начала XX в. и продолжается до середины $\mathrm{XX}$ в. Ознаменовался тем, что системность проникла во многие сферы знаний. Здесь системность уже использовалась в качестве инструмента познания.

Наконец, третий этап связан с системностью как методологией познания, этот период ознаменован началом научно-технической революции и возникает с середины XX в. Поэтому происходит активное включение системности в науку, системность используется для разработок в области технологий. Сегодня системные представления прочно вошли в современное мировоззрение, широко используются не только в философии, но и экономике, социологии, благодаря системности 
появились и успешно разрабатываются такие направления, как структурализм, структурный функционализм и другие.

\section{Литература}

1. Богданов А. А. Всеобщая организационная наука (тектология). 3-е изд. М.; Л.: Книга, 1927. Ч. 2. 240 с.

2. Берталанфи Л. История и статус общей теории систем // Системные исследования. Методологические проблемы. Ежегодник. М.: Наука, 1973. С. 20-73.

3. Винер Н. Кибернетика. М.: Советское радио, 1968. С. 34.

4. Хакен Г. Синергетика. М.: Мир, 1980. С. 12.

5. Садовский В. Н., Юдин Э. Г. Исследования по общей теории систем. М., 1974. 279 с.

6. Бранский В. П., Пожарский С. Д. Социальная синергетика и акмеология: теория самоорганизации индивидуума и социума. СПб., 2011. 159 с.

7. Степин В. С. Смена типов научной рациональности // Синергетика и психология: тексты. М., 1997. С. 108-122.

8. Аристотель. Метафизика. М., 1934. С. 102-103.

9. Горфункель А. Х. Джордано Бруно. М.: Мысль, 1965. С. 81.

10. Спицнадель В. Н. Основы системного анализа: учеб. пособие. СПб.: Бизнеспресса, 2000. С. 13.

11. Лейбниц Г. Рассуждения о метафизике // Сочинения: в 4 т. М.: Мысль, 1982. T. 1. C. 139.

12. Кант И. Сочинения: в 6 т. М., 1963. Т. 3. С. 164.

13. Цырендоржиева Д. Ш. Системный метод и синергетика в социальном познании. Улан-Удэ: Изд-во Бурят. гос. ун-та, 2005. С. 29.

14. Гегель Г. В. Ф. Сочинения. М.: Политиздат, 1932. Т. 9. С. 32.

\section{REVISITING THE EMERGENCE OF SYSTEMIC REPRESENTATIONS}

\section{Kseniya A. Bagaeva}

Cand. Sci. (Philos.), A/Prof.,

Dorzhi Banzarov Buryat State University

24a Smolina St., Ulan-Ude 670000, Russia

E-mail: ksyusha.81@mail.ru

Natalya A. Zhapova

Cand. Sci. (Philos.), Senior Lecturer,

Dorzhi Banzarov Buryat State University

24a Smolina St., Ulan-Ude 670000, Russia

E-mail: tumann4@rambler.ru

The article studies the development of systemic representations in the history of philosophic thought. It is emphasized that systemic representations were existed in antiquity starting from the mythological period. We have identified a set of categories through which the philosophers of the classical antiquity, the Middle Ages, the modern age, and also the representatives of German idealism tried to determine systematicity. The article points that systemic representations are the result of the development of philosophic thought and scientific achievements. We have distinguished three decisive stages in the development of systemic representations. It is concluded that systems theory is a universally accepted methodology for many scientific studies covering almost all branches of modern knowledge.

Keywords: system; systematicity; a whole; a part; interaction; philosophy; category. 